\title{
Correction to: Authoritarianism, trauma, and insecure bonds during the Greek economic crisis
}

\author{
Antigonos Sochos ${ }^{1}$
}

Published online: 8 March 2019

(C) Springer Science+Business Media, LLC, part of Springer Nature 2019

\section{Correction: Current Psychology https://doi.org/10.1007/s12144-018-0111-5}

The original version of this article contained a few mistakes. These have been corrected as follows:

a. In the title, the first letter of "Greek" was capitalised.

b. In the Participants section, a line before the last, the indication in brackets is (Sochos, 2018).

c. In the Procedure section, the last sentence should read "The study received ethical clearance from the Psychology Department of the University of Bedfordshire, UK".

d. The Funding section, after the Discussion, should read "This study was funded by the Research Centre for Applied Psychology, University of Bedfordshire, UK (grant number 100).

The original article has been corrected.

Publisher's note Springer Nature remains neutral with regard to jurisdictional claims in published maps and institutional affiliations.

The online version of the original article can be found at https://doi.org/ 10.1007/s12144-018-0111-5

Antigonos Sochos

antigonos.sochos@beds.ac.uk

1 Department of Psychology, University of Bedfordshire, Luton LU1 3JU, UK 